2018

\title{
Getting New Test Results to Patients
}

Sky Graybill

Brooke Army Medical Center

Joseph Kluesner

Brooke Army Medical Center

Mark True

Brooke Army Medical Center

Irene Folaron

Brooke Army Medical Center

Joshua Tate

Brooke Army Medical Center

See next page for additional authors

Tell us how you used this information in this short survey.

Follow this and additional works at: https://digitalcommons.unmc.edu/com_hosp_articles

\section{Recommended Citation}

Graybill, Sky; Kluesner, Joseph; True, Mark; Folaron, Irene; Tate, Joshua; Colburn, Jeffrey; Beckman, Darrick; and Wardian, Jana L. PhD, "Getting New Test Results to Patients" (2018). Journal Articles:

Hospital Medicine. 12.

https://digitalcommons.unmc.edu/com_hosp_articles/12

This Article is brought to you for free and open access by the Hospital Medicine at DigitalCommons@UNMC. It has been accepted for inclusion in Journal Articles: Hospital Medicine by an authorized administrator of DigitalCommons@UNMC.For more information, please contact digitalcommons@unmc.edu. 


\section{Authors}

Sky Graybill, Joseph Kluesner, Mark True, Irene Folaron, Joshua Tate, Jeffrey Colburn, Darrick Beckman, and Jana L. Wardian PhD

This article is available at DigitalCommons@UNMC: https://digitalcommons.unmc.edu/com_hosp_articles/12 


\section{Getting New Test Results to Patients}

Sky Graybill, MD; Joseph Kluesner, MD; Mark True, MD; Irene Folaron, MD; Joshua Tate, MD; Jeffrey Colburn, MD; Darrick Beckman, MD; Jana Wardian, PhD

New diagnostic results are constantly arriving to outpatient practices. It is imperative to effectively communicate these results and their implications to patients. Methods: We surveyed 100 patients and our clinic personnel to assess opinions regarding methods of communication in common scenarios. Results: Response rate was $79 \%$ from patients and $75 \%$ from clinic personnel. Most patients thought letters were an appropriate way to receive normal test results (83\%). They also felt medical-technician calls were appropriate for normal results $(88 \%)$, medication dose changes $(75 \%)$, or need for additional studies $(71 \%)$. Respondents considered nurse calls acceptable in most scenarios except for new diagnoses of cancer or need for surgery; the consensus was that physicians should directly communicate to patients in these situations. Conclusions: Providers should take the time to discuss results with patients that lead to significant interventions, but employ support staff to disseminate information about normal results, medication dose changes, and need for additional diagnostic testing.

Key words: communication, outpatients, test results

M edical providers work in an environment of competing priorities. Patient care, administrative services, continuing education, and research contend for physicians' time and attention. Clinic providers often spend nearly 2 hours on paperwork for every hour spent in face-to-face patient contact, ${ }^{1}$ creating inefficiencies in the delivery of care. Despite this burden, underutilization of staff is common. ${ }^{2}$ However, nurses, medical-technicians, and other ancillary clinical staff can learn to handle many of these administrative tasks, especially with today's technological advances. Teambased patient care can liberate physicians to concentrate upon those tasks that require their professional

\footnotetext{
Author Affiliations: Brooke Army Medical Center, San Antonio, Texas (MAJ Graybill, CPT Kluesner, COL True, LTC Folaron, CPT Tate; MAJ Colburn, and MAJ Beckman); and Wilford Hall Ambulatory Surgical Center, San Antonio, Texas (Dr Wardian).
}

Correspondence: Sky Graybill, MD, Brooke Army Medical Center, 3551 Roger Brooke Dr, San Antonio, TX 78219 (sky.d.graybill.mil@mail.mil; skydenniston@yahoo.com).

MAJ Graybill designed the study, collected data, reviewed the literature, analyzed the data, and drafted the manuscript; CPT Kluesner assisted with data collection, literature review, and revised the manuscript; COL True inspired publication of this project, assisted with study design, and revised the manuscript; LTC Folaron assisted with data analysis and revised the manuscript; CPT Tate assisted with literature review and revised the manuscript; MAJ Colburn assisted with literature review and revised the manuscript; MAJ Beckman assisted with study design and revised the manuscript; and Dr Wardian reviewed the literature, assisted with data analysis, and revised the manuscript. The authors take public responsibility for the content of this manuscript and adhered to ethical standards. They declare that there are no conflicts of interest.

The views expressed herein are those of the authors and do not reflect the official policy or position of Brooke Army Medical Center, the US Army Medical Department, the US Army Office of the Surgeon General, the Department of the Army, the Department of the Air Force, Department of Defense, or the US Government.

Q Manage Health Care

Vol. 27, No. 3, pp. 145-150

Copyright (C) 2018 Wolters Kluwer Health, Inc. All rights reserved.

DOI: $10.1097 / 0 \mathrm{MH} .0000000000000178$ expertise and empower other team members to develop skills under indirect supervision.

In our outpatient endocrine clinic, we identified an area of inefficiency with our methods of communicating diagnostic results to our patients. Our practice consists of 4 staff endocrinologists, 3 endocrine fellows, 1 nurse, 1 fellowship program coordinator, 1 receptionist, and 6 medical-technicians.

Our clinic predominately relied on the 7 physicians to directly communicate diagnostic results to patients. Because of competing demands on their time, we realized that this was not a sustainable approach. We recognized that some existing methods of efficiency were already in place, such as mailing results to patients or allowing them to review their results in an online medical record. In addition, the medical-technicians contact patients prior to clinic appointments to assist them with undergoing diagnostic studies that appear necessary based on the consult. This allows providers to discuss many results during the initial patient face-to-face encounter. However, there are still numerous test results that become available after these encounters.

Medical-technicians receive 4 months of emergency medical education prior to clinical responsibility, followed by on-the-job training. Medical-technicians can provide some advice to patients, but currently there is little guidance regarding their purview in communicating with patients. Dr Eden ${ }^{3}$ describes ways to employ medical assistants that are cost-effective and safe. We designed a process improvement project to facilitate communication with patients that was efficient for physicians and as well as acceptable to patients.

\section{METHODS}

\section{Design}

Upon review of the project, our institution's Exemption Determination Officer concluded that it did not require institutional review board approval. We distributed 100 surveys to patients and 16 to clinical personnel. The 
survey's collection time period was from October through November 2016. The setting was a military endocrine clinic. Common conditions in this clinic are thyroid nodules, thyroid cancer, osteoporosis, hypogonadism, and adrenal and pituitary disorders; we provide diabetes care in another specialty clinic. Thyroid biopsies, laboratory tests, and radiology studies regularly produce new results.

The survey (Figure 1) asked about preferred methods of communication to include online review by patients, mailed letters, calls from medical-technicians, nurses, or physicians, and returning for face-to-face visits. Furthermore, the survey included questions about a variety of common scenarios: continuation of current treatment plans, medication dose adjustments, new medications, additional testing, repeat biopsies, surgery, or diagnoses of cancer. Respondents indicated which methods they felt were (1) acceptable, (2) not acceptable, or (3) optimal.

\section{Data analysis}

We entered survey responses into an online survey collection tool, which assisted with tallying patient and staff responses. This descriptive analysis compared responses of "acceptable" and "optimal" with responses of "not acceptable" for each scenario.

\section{RESULTS}

We received 79 of 100 patient (79\% response rate) and 12 of 16 medical staff surveys (75\% response rate). Nine patient surveys were discarded because respondents gave the same answer for every question, raising suspicion that they were not thoughtfully completed. Not all respondents answered every question.

\section{Normal test results}

For normal results that lead to no change in plans (Figures 2A and 2B), the majority of patients responded that letters were acceptable (83\%). They were also comfortable with medical-technician calls (88\%) or nurse calls $(98 \%)$. Nearly half of patients responded that looking up results online was not acceptable (49\%). Most clinical staff members (92\%) answered that it was optimal or acceptable for patients to review normal results online (92\%) or receive a letter about them $(83 \%)$. Clinical staff answered that it was not acceptable to require physicians to call all patients (58\%) or require patients to return for appointments to review normal results $(92 \%)$.

\section{Medication dosage changes}

For results indicating dose changes (Figures 2C and 2D), the majority of patients were comfortable with medical-technician calls $(75 \%)$ or nurse calls $(93 \%)$.

\begin{tabular}{|c|c|c|c|c|c|c|}
\hline & $\begin{array}{l}\text { Physician to call } \\
\text { patient }\end{array}$ & $\begin{array}{l}\text { Physician to send } \\
\text { letter to patient }\end{array}$ & $\begin{array}{l}\text { Patient to return } \\
\text { for a face-to-face } \\
\text { visit with physician }\end{array}$ & $\begin{array}{l}\text { Nurse to call } \\
\text { patient with } \\
\text { message from } \\
\text { physician }\end{array}$ & $\begin{array}{l}\text { Medical technician } \\
\text { to call patient with } \\
\text { message from } \\
\text { physician }\end{array}$ & $\begin{array}{l}\text { Patient to look up } \\
\text { results on } \\
\text { tricareonline.com }\end{array}$ \\
\hline $\begin{array}{l}\text { Normal results that lead } \\
\text { to no change in plans }\end{array}$ & $\begin{array}{l}\square \text { Acceptable } \\
\square \text { Not } \\
\text { acceptable } \\
\square \text { Optimal }\end{array}$ & $\begin{array}{l}\square \text { Acceptable } \\
\square \text { Not } \\
\text { acceptable } \\
\square \text { Optimal }\end{array}$ & $\begin{array}{ll}\square & \text { Acceptable } \\
\square & \text { Not } \\
\text { acceptable } \\
\square \text { Optimal }\end{array}$ & $\begin{array}{l}\square \text { Acceptable } \\
\square \text { Not } \\
\text { acceptable } \\
\square \text { Optimal }\end{array}$ & $\begin{array}{l}\square \text { Acceptable } \\
\square \text { Not } \\
\text { acceptable } \\
\square \text { Optimal }\end{array}$ & $\begin{array}{l}\square \text { Acceptable } \\
\square \text { Not } \\
\text { acceptable } \\
\square \text { Optimal }\end{array}$ \\
\hline $\begin{array}{l}\text { Results indicate a dose } \\
\text { change for a medication } \\
\text { patient is already taking }\end{array}$ & $\begin{array}{ll}\square & \text { Acceptable } \\
\square \text { Not } \\
\text { acceptable } \\
\square \text { Optimal }\end{array}$ & $\begin{array}{ll}\square & \text { Acceptable } \\
\square & \text { Not } \\
\text { acceptable } \\
\square \text { Optimal }\end{array}$ & $\begin{array}{ll}\square & \text { Acceptable } \\
\square & \text { Not } \\
\text { acceptable } \\
\square \text { Optimal }\end{array}$ & $\begin{array}{l}\square \text { Acceptable } \\
\square \text { Not } \\
\text { acceptable } \\
\square \text { Optimal }\end{array}$ & $\begin{array}{l}\square \text { Acceptable } \\
\square \text { Not } \\
\text { acceptable } \\
\square \text { Optimal }\end{array}$ & $\begin{array}{l}\square \text { Acceptable } \\
\square \text { Not } \\
\text { acceptable } \\
\square \text { Optimal }\end{array}$ \\
\hline $\begin{array}{l}\text { Results that indicate } \\
\text { starting a new } \\
\text { medication }\end{array}$ & $\begin{array}{l}\square \text { Acceptable } \\
\square \text { Not } \\
\text { acceptable } \\
\square \text { Optimal }\end{array}$ & $\begin{array}{ll}\square & \text { Acceptable } \\
\square & \text { Not } \\
\text { acceptable } \\
\square \text { Optimal }\end{array}$ & $\begin{array}{ll}\square & \text { Acceptable } \\
\square & \text { Not } \\
\text { acceptable } \\
\square \text { Optimal }\end{array}$ & $\begin{array}{l}\square \text { Acceptable } \\
\square \text { Not } \\
\text { acceptable } \\
\square \text { Optimal }\end{array}$ & $\begin{array}{l}\square \text { Acceptable } \\
\square \text { Not } \\
\text { acceptable } \\
\square \text { Optimal }\end{array}$ & $\begin{array}{ll}\square & \text { Acceptable } \\
\square & \text { Not } \\
\text { acceptable } \\
\square \text { Optimal }\end{array}$ \\
\hline $\begin{array}{l}\text { Results that indicate } \\
\text { additional laboratory or } \\
\text { radiology studies }\end{array}$ & $\begin{array}{l}\square \text { Acceptable } \\
\square \text { Not } \\
\text { acceptable } \\
\square \text { Optimal }\end{array}$ & $\begin{array}{l}\square \text { Acceptable } \\
\square \text { Not } \\
\text { acceptable } \\
\square \text { Optimal }\end{array}$ & $\begin{array}{ll}\square & \text { Acceptable } \\
\square & \text { Not } \\
\text { acceptable } \\
\square \text { Optimal }\end{array}$ & $\begin{array}{l}\square \text { Acceptable } \\
\square \text { Not } \\
\text { acceptable } \\
\square \text { Optimal }\end{array}$ & $\begin{array}{l}\square \text { Acceptable } \\
\square \text { Not } \\
\text { acceptable } \\
\square \text { Optimal }\end{array}$ & $\begin{array}{l}\square \text { Acceptable } \\
\square \text { Not } \\
\text { acceptable } \\
\square \text { Optimal }\end{array}$ \\
\hline $\begin{array}{l}\text { Indeterminate biopsy } \\
\text { indicates repeat } \\
\text { biopsy }\end{array}$ & $\begin{array}{l}\square \text { Acceptable } \\
\square \text { Not } \\
\text { acceptable } \\
\square \text { Optimal }\end{array}$ & $\begin{array}{l}\square \text { Acceptable } \\
\square \text { Not } \\
\text { acceptable } \\
\square \text { Optimal }\end{array}$ & $\begin{array}{ll}\square & \text { Acceptable } \\
\square & \text { Not } \\
\text { acceptable } \\
\square \text { Optimal }\end{array}$ & $\begin{array}{ll}\square & \text { Acceptable } \\
\square & \text { Not } \\
\text { acceptable } \\
\square \text { Optimal }\end{array}$ & $\begin{array}{l}\square \text { Acceptable } \\
\square \text { Not } \\
\text { acceptable } \\
\square \text { Optimal }\end{array}$ & $\begin{array}{l}\square \text { Acceptable } \\
\square \text { Not } \\
\text { acceptable } \\
\square \text { Optimal }\end{array}$ \\
\hline $\begin{array}{l}\text { Results that indicate } \\
\text { surgery }\end{array}$ & $\begin{array}{l}\square \text { Acceptable } \\
\square \text { Not } \\
\text { acceptable } \\
\square \text { Optimal }\end{array}$ & $\begin{array}{l}\square \text { Acceptable } \\
\square \text { Not } \\
\text { acceptable } \\
\square \text { Optimal }\end{array}$ & $\begin{array}{ll}\square & \text { Acceptable } \\
\square & \text { Not } \\
\text { acceptable } \\
\square \text { Optimal }\end{array}$ & $\begin{array}{l}\square \text { Acceptable } \\
\square \text { Not } \\
\text { acceptable } \\
\square \text { Optimal }\end{array}$ & $\begin{array}{l}\square \text { Acceptable } \\
\square \text { Not } \\
\text { acceptable } \\
\square \text { Optimal }\end{array}$ & $\begin{array}{l}\square \text { Acceptable } \\
\square \text { Not } \\
\text { acceptable } \\
\square \text { Optimal }\end{array}$ \\
\hline $\begin{array}{l}\text { Results give a new } \\
\text { diagnosis of cancer }\end{array}$ & $\begin{array}{l}\square \text { Acceptable } \\
\square \text { Not } \\
\text { acceptable } \\
\square \text { Optimal }\end{array}$ & $\begin{array}{l}\square \text { Acceptable } \\
\square \text { Not } \\
\text { acceptable } \\
\square \text { Optimal }\end{array}$ & $\begin{array}{ll}\square & \text { Acceptable } \\
\square \text { Not } \\
\text { acceptable } \\
\square \text { Optimal }\end{array}$ & $\begin{array}{l}\square \text { Acceptable } \\
\square \text { Not } \\
\text { acceptable } \\
\square \text { Optimal }\end{array}$ & $\begin{array}{l}\square \text { Acceptable } \\
\square \text { Not } \\
\text { acceptable } \\
\square \text { Optimal }\end{array}$ & $\begin{array}{ll}\square & \text { Acceptable } \\
\square \text { Not } \\
\text { acceptable } \\
\square \text { Optimal }\end{array}$ \\
\hline
\end{tabular}

Figure 1. Survey form. BRMC indicates Brooke Army Medical Center. 

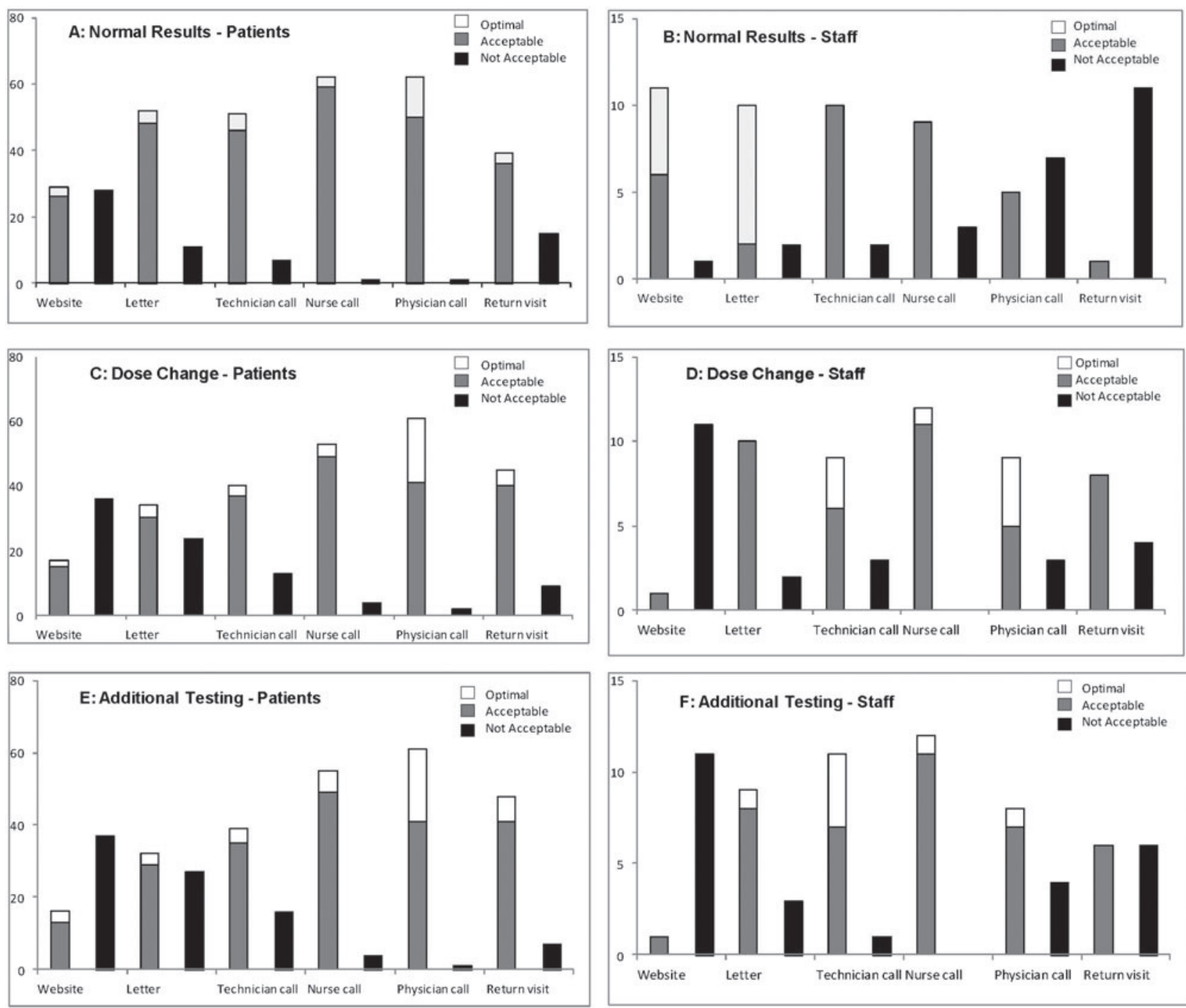

Figure 2. Survey results for scenarios requiring no to minimal interventions. Letters, medical-technician, and nurse calls were appropriate for normal results according to patients $(A)$ and staff $(B)$. Medical-technician or nurse calls were appropriate for medication dose changes per patients (C) and staff (D). Additionally, medical-technician or nurse calls were appropriate to communicate the need for additional laboratory or radiology studies per patients $(E)$ and staff $(F)$.

Patients answered that it was not acceptable to receive letters $(41 \%)$ or review these results online (68\%). However, the majority of clinical personnel were in agreement that it was appropriate to transmit dosage changes by letter (83\%), medical-technician calls $(75 \%)$, or nurse calls $(100 \%)$.

\section{Additional testing}

For results indicating additional laboratory or radiology studies (Figures 2E and 2F), patients responded that it was appropriate to communicate this information by medical-technician calls (71\%) and nurse calls $(93 \%)$. Clinical personnel agreed that it was acceptable or optimal to transmit this information by medical-technician (92\%) or nurse calls (100\%).

\section{New medication}

For results that indicate starting a new medication

(Figures $3 \mathrm{~A}$ and $3 \mathrm{~B}$ ), patients responded that it was acceptable to communicate this by medical-technician calls $(68 \%)$ or nurse calls $(93 \%)$. Clinical personnel sharply disagreed and responded that is was not acceptable to communicate starting a new medication by medical-technician calls (75\%) or nurse calls $(67 \%)$.

\section{Indeterminate biopsies}

For indeterminate biopsies that indicated repeat biopsies (Figures 3C and 3D), patients responded that it was acceptable to communicate this by medical-technician calls (58\%) but many preferred nurse calls (79\%). Clinical personnel responded that it was acceptable to communicate indeterminate biopsy results by medicaltechnician calls (58\%), but they also favored nurse calls (92\%).

\section{Results indicating surgery}

For results that indicate surgery (Figures 4A and $4 \mathrm{~B})$, patients responded it was not acceptable to 

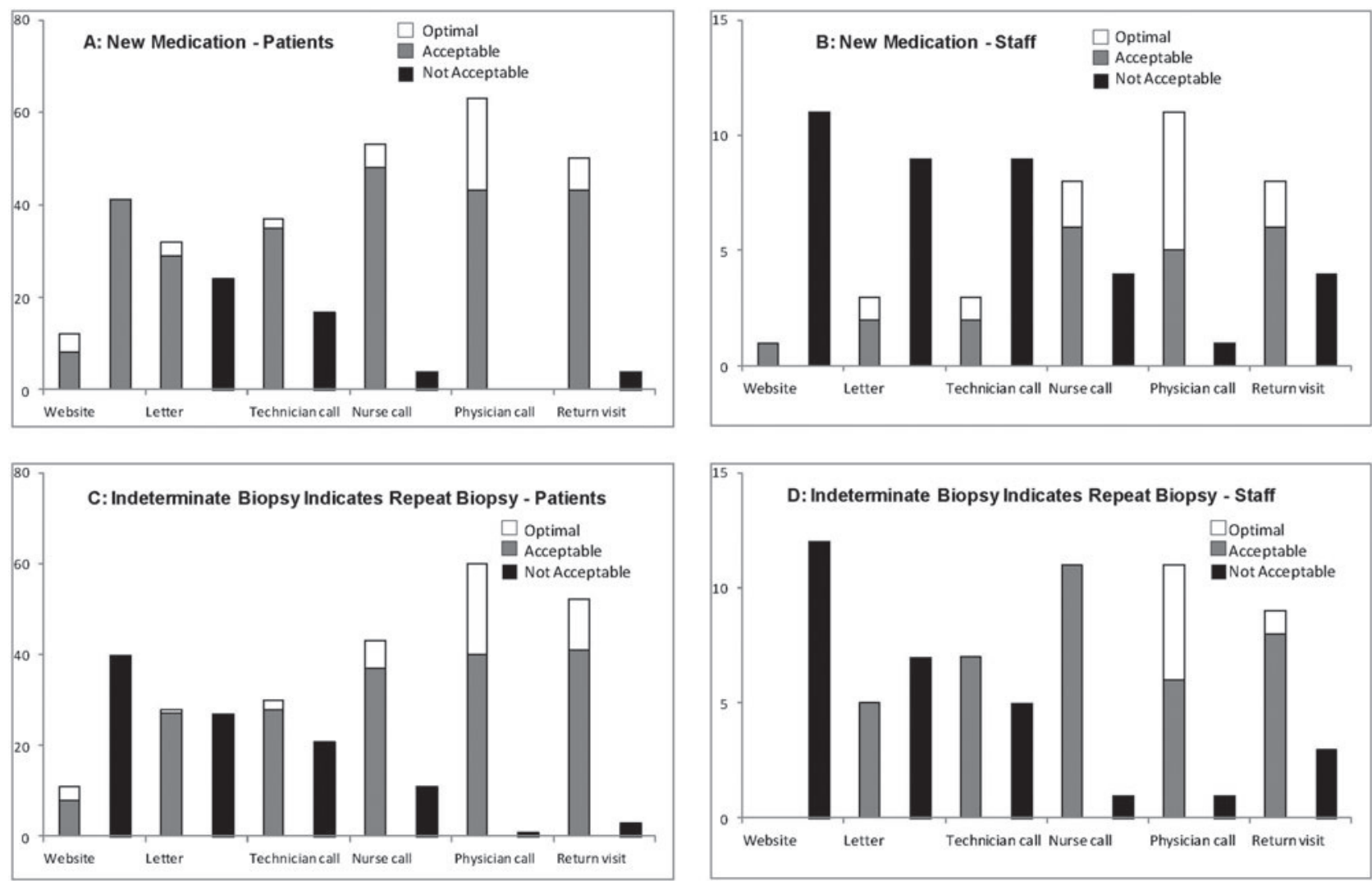

Figure 3. Survey results for scenarios requiring moderate interventions. Patients and clinic personnel did not agree about support staff communicating the need to start a new medication with patients finding this acceptable (A) but staff arguing that the physician should do it (B). Nurse calls were appropriate for communicating indeterminate biopsy results according to patients (C) and staff (D).

communicate this by medical-technician calls $(59 \%)$ or nurse calls $(47 \%)$. Clinical personnel responded that is was not acceptable to discuss surgery by medicaltechnician calls $(100 \%)$ or nurse calls $(75 \%)$. Both patients and staff overwhelmingly favored physician calls or a return visit.

\section{Cancer diagnosis}

For a new diagnosis of cancer (Figures 4C and 4D), patients responded that it was not acceptable to receive this news by medical-technician calls $(72 \%)$ or nurse calls $(68 \%)$. Clinical personnel agreed that it was not acceptable to give a diagnosis of cancer by medicaltechnician calls $(100 \%)$ or nurse calls $(92 \%)$. Patients and clinical personnel clearly favored return visits for this discussion.

\section{Limitations}

We did not collect demographic information or personal medical history because it did not fit on the 1-page survey; we thought limiting questions to 1 page would improve response rates. In addition, not all respondents answered each question. Furthermore, the survey collection time period was only 2 months. The survey question order may have influenced respondents' sense of question importance. Many respondents were unfamiliar with the support staff skills and BAMC (Brooke Army Medical Center) Web site capa- bilities. Finally, there are no licensed practical nurses, nurse practitioners, or physician assistants in our clinic, so this project does not specifically include their role.

\section{DISCUSSION}

Good communication with medical providers improves psychological outcomes for patients. ${ }^{4-6}$ When selecting a method of communication, it is important to assess how new test results might impact people emotionally. When scenarios require no new interventions, patients are generally satisfied with a letter. In scenarios requiring minor interventions, such as additional laboratory studies or medication dose changes, patients are usually content to hear from a medical-technician or nurse. In scenarios requiring higher-risk interventions, such as surgery or cancer management, patients strongly desired to communicate directly with their physicians.

Physicians are legally responsible for new results and may feel compelled to personally call their patients or have them return to the clinic for test reviews. However, time constraints make this difficult and inefficient and may distract from other important responsibilities. Patients consistently preferred staff contact to letters or website reviews. They especially favored communication with physicians. However, in many scenarios, many patients also responded that support staff calls or letters were acceptable. In contrast, clinical staff 

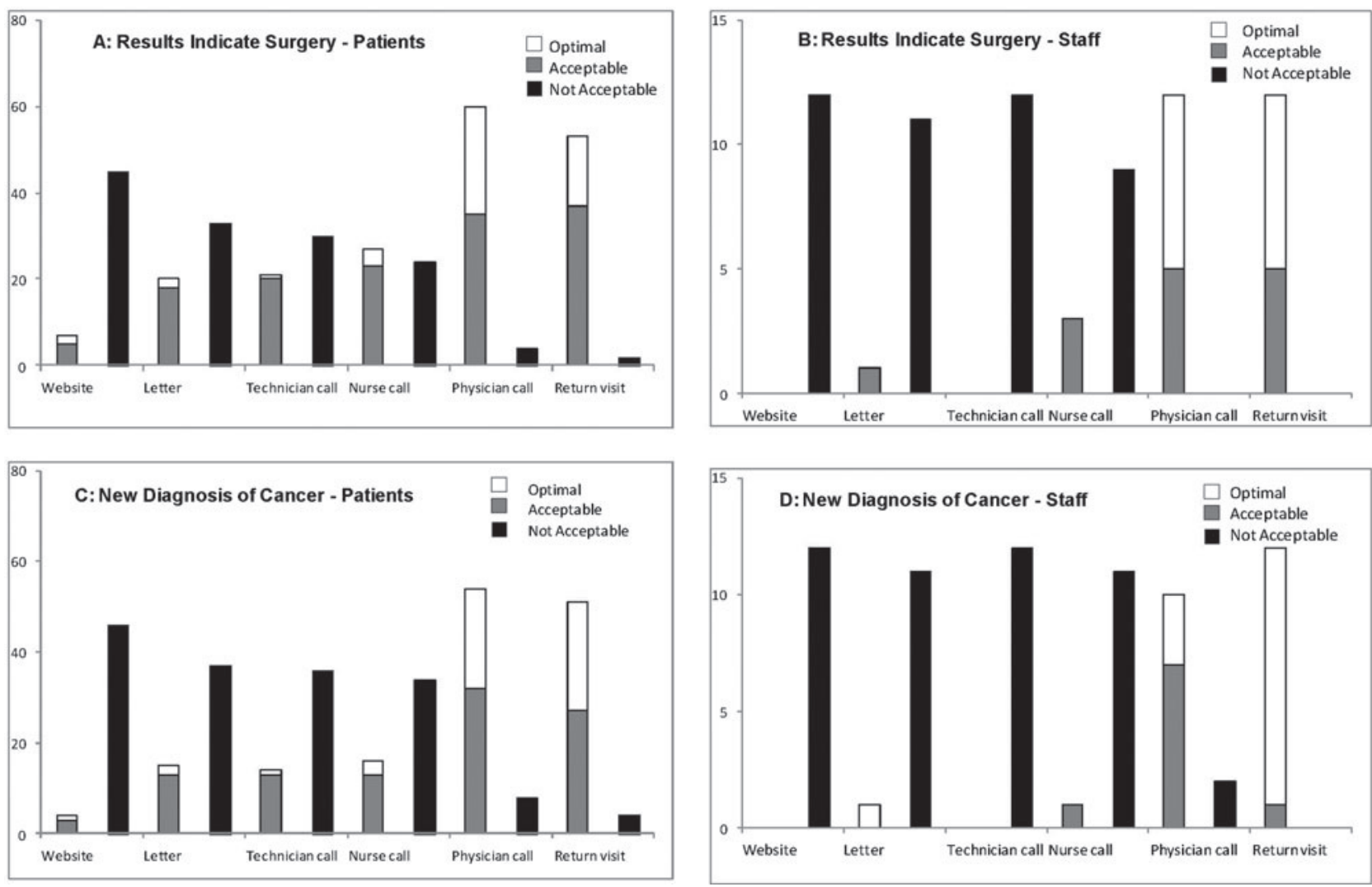

Figure 4. Survey results for scenarios requiring substantial interventions. Patients (A) and staff (B) preferred physician calls or return visits to discuss a need for surgery. Patients (C) and staff (D) also preferred physician calls or return visits to discuss a new diagnosis of cancer.

responded that it was not acceptable for physicians to spend time calling patients with normal results or to schedule a return visit. Patients and staff felt a nurse call was acceptable in most scenarios. However, a majority of patients felt that a new diagnosis of cancer or the need for surgery should include the physician.

There is currently a dearth of medical literature for outpatient clinical efficiency. Most efficiency studies come from industry, ${ }^{7}$ particularly car manufacturing and aviation. Medical systems can infer many valuable lessons from these sources. However, the medical field is unique in that it impacts both pathology of the human body and emotions; it needs workflow efficiency research that takes these factors into account.

Our project demonstrates that our patients value the convenience of phone calls. Other studies show that patients are increasingly requesting e-mails, phone calls, and Web-based communication with their health care providers. ${ }^{8,9}$ Telemedicine is an option that saves travel and medical costs, especially for chronic conditions. ${ }^{10,11}$ It requires a user-friendly platform that addresses malpractice and reimbursement. ${ }^{12,13}$ However, medical providers often do not get reimbursed for phone calls and other forms of telemedicine. ${ }^{14}$ Some insurance companies are starting to reimburse for these services, particularly in the private sector. ${ }^{15-17}$ Nationally, medical systems and insurance companies should consistently reimburse clinics for phone calls, as they can reduce costs while improving patient satisfaction and efficiency.

An unexpected outcome of the survey was the difference between patient and medical staff responses regarding communication about starting new medication. Patients were favorable toward support staff calls. It could be that patients were unaware of the limited pharmaceutical knowledge of our medical support staff or that they were content to rely upon the pharmacist for additional information. However, it is even more likely that the survey question order influenced patient responses. Most of the survey questions went from least to most invasive. The one exception to this was for starting new medication. If other clinics wish to use this or a similar survey, it may be best to place the questions about additional laboratory or radiology studies before the questions about starting new medication.

\section{CONCLUSION}

Physicians should take the time to discuss major issues such as surgery or cancer management with their patients. However, they can delegate the dissemination of routine results or minor treatment plan adjustments to support staff because this is generally acceptable to 
patients. This will significantly improve efficiency and permit physicians to utilize their time in the most productive manner.

\section{IMPLICATIONS}

As a result of this project, our clinic made changes in our standard practices to improve efficiency. Medicaltechnicians now send letters to patients or call them with normal results, medication dose changes, or the need for additional studies. Other outpatient clinics may want to consider whether establishing similar practices would liberate their physicians to concentrate upon duties that support staff cannot perform.

Clinics may benefit from conducting similar projects to improve their local patient care delivery and policies about test result communications. Medical clinics may benefit from delegating support staff to communicate about less invasive interventions, reserving physician communications concerning serious diagnoses or new treatment (new medication or surgery). Outpatient clinics could adapt our survey to their patient populations. Physician time is costly and is a primary bottleneck in health care. Alleviating this bottleneck has potential to improve patient care.

\section{REFERENCES}

1. Sinsky C, Colligan L, Li L, et al. Allocation of physician time in ambulatory practice: a time and motion study in 4 specialties. Ann Intern Med. 2016:165(11):753-760.

2. Teich ST, Faddoul FF. Lean management-the journey from Toyota to healthcare. Rambam Maimonides Med J. 2013;4(2):e0007.

3. Eden RS. Maximizing your medical assistant's role. Fam Pract Manag. 2016;23(3):5.
4. Cao W, Xiaona Ql, Yao T, Han X, Feng X. How doctors communicate the initial diagnosis of cancer matters: cancer disclosure and its relationship with patients' hope and trust. Psychooncology. 2017;26(5):640-648.

5. Jackson D, Roberts G, Wu ML, Ford R, Doyle C. A systematic review of the effect of telephone, Internet or combined support for carers of people living with Alzheimer's, vascular or mixed dementia in the community. Arch Gerontol Geriatr. 2016;66:218236.

6. Anderson PF, Wescom E, Carlos RC. Difficult doctors, difficult patients: building empathy. J Am Coll Radiol. 2016;13(12):15901598.

7. D'Andreamatteo A, lanni L, Lega F, Sargiacomo M. Lean in healthcare: a comprehensive review. Health Policy. 2015;119(9):11971209.

8. Kittler A, Pizziferri L, Volk L, Jagannath Y, Wald J, Bates D. Primary care physician attitudes towards using a secure Web-based portal designed to facilitate electronic communication with patients. J Innov Health Inform. 2004;12(3):129-138.

9. Liederman EM, Morefield CS. Web messaging: a new tool for patient-physician communication. J Am Med Inform Assoc. 2003; 10(3):260-270.

10. Balaraman Rajan AS, Dorsey E. The competitive business impact of using telemedicine for the treatment of patients with chronic conditions. J Manage Inf Syst. 2013;30(2):127-158.

11. Mazur L. View from McDermott: is telemedicine the potential solution to the looming 'Cadillac tax' and to improving employee health? Manag Benefits Plans. 2016;18(2):9-13.

12. Frederick $S$. The key to making telemedicine work. Health Manage Technol. 2013;34(4):12.

13. Hsieh HL, Tsai $\mathrm{CH}$, Chih WH, Lin HH. Factors affecting success of an integrated community-based telehealth system. Technol Health Care. 2015;23:S189-S196.

14. Zimlich R. Telemedicine: an economic evaluation Managed Health Executive. 2016;26(2):17-19.

15. Lacktman N. Five telemedicine trends transforming health care in 2016. Telemedicine. 2016;43-58.

16. Morrissey, J. Telemedicine today. Trustee. 2012;65(2):8-11.

17. Sherling M. Phone it in: a perfect storm takes telemedicine to new heights. Health Manage Technol. 2016;37(3):18. 